\title{
FAKİR BAYKURT’UN “IRAZCA’NIN DİRLİĞİ” ROMANININ YAPISAL ÇÖZÜMLEMESİ
}

\section{STRUCTURAL ANALYSIS OF “IRAZCA'NIN DİRLİĞI” BY FAKİR BAYKURT \\ СТРУКТУРНЫЙ АНАЛИЗ ГОМАНА ФАКИРА БАЙКУРТ "IRAZCA'NIN DİRLİĞİ"}

Okan ÖZKARA*

\section{$\ddot{O Z Z}$}

Her roman, teknik bakımdan bir bütünlük içerisinde çeşitli yapı unsurlarından oluşur. Romanda anlam bütünlüğünün sağlanması, yapısalcı bakış açısı ile yapısal unsurların kurgulanma ve kullanılma biçimine bağlıdır. İnceleme içerisinde yapı; Romanın Kimliği, İsimden İçeriğe, Bakış Açısı ve Anlatıcı, Olay Örgüsü, Zaman, Mekan ve Kişiler Düzlemi başlıkları altında tespit edilmeye çalışılmış ve bu yapının gösterdiği anlam örüntülerine değinilmiştir. Mekan çözümlemesinde, mekana yüklenen algısal yük esas alınarak darlaşan/labirentleşen ve genişleyen mekanlar; kişiler düzleminde ise, başkişi ve başkişinin etrafında şekillenen norm, kart ve fon kişiler tespit edilmiştir.

Huzur arayışında olan Cumhuriyet sonrası dönem Anadolu insanının yaşamsal sorunlarının anlam bulduğu Irazca'nın Dirliği romanı, Fakir Baykurt anlatılarının ortak çıkış noktasını oluşturan toplumsal eşitsizliği konu edinir. Romanda anlam bütünlüğünün sağlanabilmesinde yol gösterici olan yapı unsurları, romanın başkişisi olan Irazca etrafındaki anlam örüntülerini aydınlatmak amacıyla çözümlenmiştir.

Açar Sözcükler: Yapısalcılık, Roman Tekniği, Fakir Baykurt, Irazca’nın Dirliği, Algisal Mekan.

\section{ABSTRACT}

In terms of technical arrangement, each novel is made up of various constructive elements. Achievement of meaning in a novel depends greatly upon the arrangement and use of structure elements, when vieving the novel from a structural standpoint. The structure in the novel is achieved through the examination of identity of the novel, from the title to the content, point of view and the narrator, plot, time, setting and personalities, and the interrelation between meaning and structure is analyzed. In the analysis of setting (namely space) the meaning attached to space is taken into consideration and the setting is considered as narrowing, labyrinth or widening setting; and in the analysis of personea, the normative, decorative and stereotypical caharacters are detected so as to shed light on the main character.

Irazca'nın Dirliği, in which the life matters of Anatolian people, who are in search of a peaceful lifestyle following the foundation of Turkish Republic, mainly focuses upon social inequality, which forms the main axis of Fakir Baykurt's novels. Structural elements that

*Ardahan Üniversitesi, Türk Dili Okutmanı, okanozkara@ardahan.edu.tr. 10.17498/kdeniz.279661 
are helpful in understanding the meaning entity of the novel are examined so as to throw light upon the life of the protagonist, Irazca.

Key Words: Structuralism, Novel Technique, Fakir Baykurt, Irazca'nın Dirliği (Irazca's Peace), Perceptive Space.

\section{АННОТАЦИЯ}

Bсе романы, с точки зрения своей структуры, являются синтезом разных элементов. Целосность самого романа связано с последовательностю и формой по использований структурных элементов. Анализ был проведён по следующим вопросам: идентичность романа,от названия $\kappa$ содержанию, точка зрения $и$ рассказчик, динамика событий, время, место и действующце лица. Затронуты смысловые аспекты структуры романа. Анализ времены был проведён на основе перцептивных нагрузков. Были выявлены лабиринты и расширенные пространства; а при установлении плоскостей нахождения героев, были установлены нормы, плохие и неважные характеры.

Основной темой романа является социальное неравенство, в рамках которого народ Анатолии, после становления республики, ищет спокойствие и ответ на жизненные проблемы. Сруктурные элементы романа разрешены с челью разьяснения аспектов, связанных с главным героем по имени Иразджа.

Ключевые слова: Структурализм, техника романа, Факир Байкурт, Баллада Иразджы, перцептивное пространство.

\section{Giriş}

Fakir Baykurt'un Irazca 'nın Dirliği adlı romanı, Cumhuriyet'in ilk yıllarında dışarıdan gelen sorun ve zorunluluklarla Anadolu insanının köy yaşamından kent yaşamına itildiğinin sembolik yargılarla anlatıldığı bir köy romanıdır. Yaşadığı coğrafyayı iyi gözlemleyerek analiz eden yazar, eserinde; kişiler düzleminde huzur arayan Irazca ve Irazca'nın ailesinin karşısına, onların dirliğini bozmaya çalışan bazı karşı değerler çıkarır. Bu engellerle savaş halinde olan aile, aynı zamanda, kavramlar düzleminde; geçmişe özlem, sömürü, sosyal adaletsizlik, sınıf çatışması, bürokratik çürüme, yoksulluk gibi karşı değerler ile sevgi, fedakarlık, sadakat, yaşama tutunma arzusu gibi ülkü değerlerin çatışmasına yön verir. Adı geçen kavramların ve kişilerin çatışması sonucu oluşan sosyal yapı, dönemin sosyal yapısını yansıtması yönüyle de önemlidir.

Yapı bağlamında "romanın kimliği, isimden içeriğe, bakış açısı ve anlatıcı, olay örgüsü, zaman, mekan ve kişiler düzleminin" farklı başlıklar altında incelendiği çalışmanın Romanın Kimliği bölümünde, romanın ilk ve son baskısının tarihlerinin yanı sıra ana izleğine değinilir. İsimden İçeriğe bölümünde, karşılaştırma yapılarak romanın isim analizinin içerikle olan ilişkisi açıklanır. Bakış Açısı ve Anlatıcı bölümünde, hakim bakış açısı ön plandayken yazarın kullanım alanları belirtilir. Dört vaka halkası altında kırk altı bölüm olarak değerlendirilebilecek olan Olay Örgüsü kısmında romanın oluşumu ve bütünlüğü hakkında bilgi verilirken; vaka zamanı, nesnel zaman ve öykü zamanı hakkındaki görüşler ve roman içerisinde an'a gönderme yapan kısımlar Zaman başlığı altında değerlendirilir. Çevresel ve algısal mekanlara değinilen Mekan başlığı altında, romanın içselleştiği açık/geniş ve kapalı/dar (labirentleşen) mekanlar açıkça belirtilir. Yapı çalışmasının son ana başlığında roman içerisindeki Kişiler Düzlemi değerlendirilirken, 
başkişi, norm kişiler ve kart karakterlerin yanı sıra sıkça karşılaşılan fon karakterlerin varlık alanlarından bahsedilir. $\mathrm{Bu}$ bağlamda, çalışmanın oluşumunu gösteren şemada yapı unsurları ayrıca belirtilmiştir:

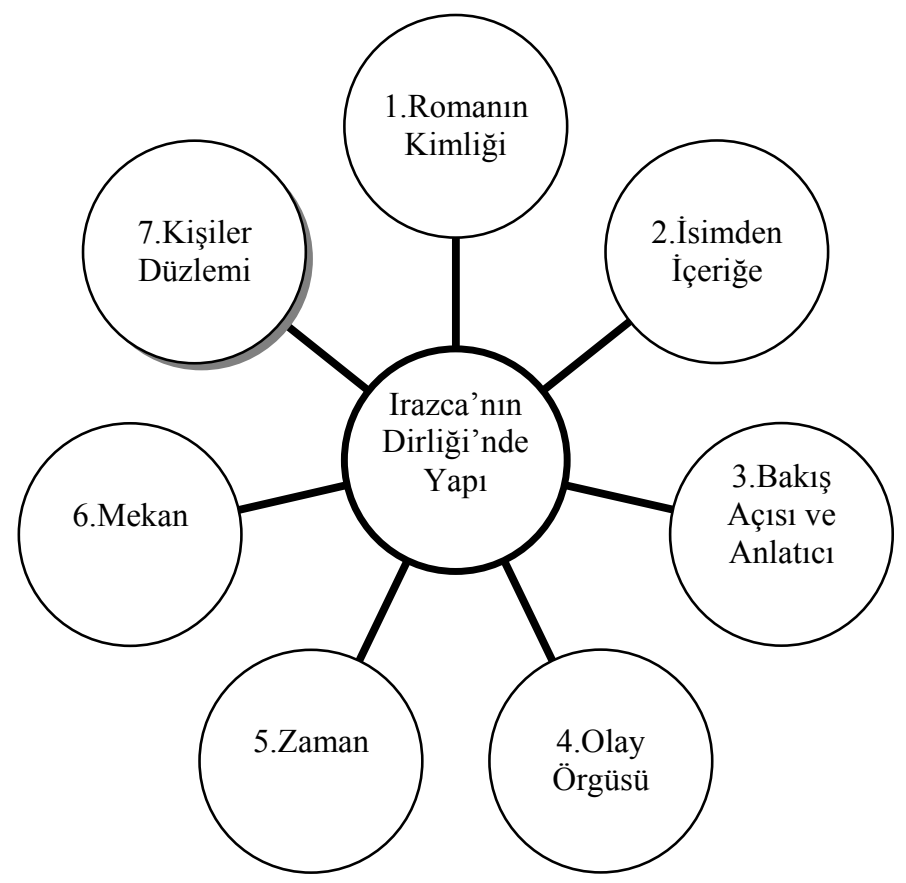

\section{Şema: Irazca'nın Dirliği’nde Yapı}

\section{Romanın Kimliği}

Fakir Baykurt'un 1960 yılında tamamladığı Irazca'nın Dirliği adlı romanının ilk baskısı 1961 yılında Remzi Kitabevi tarafından yayımlanır. Karataş köyünün ve idari gücü elinde bulunduran kişilerin Irazca'nın ailesine karşı olan tutumunun bir yansıması olarak doğan roman; Yılanların Öcü, Irazca'nın Dirliği, Kara Ahmet Destanı üçlemesinin ikinci romanıdır. Irazca 'nın Dirliği'nin bugüne kadarki son baskısı (On altıncı baskı) 2015 yılında Literatür Yayınları tarafından yayımlanır.

Eser, hayatı boyunca gün yüzü görmemiş Irazca'nın, ailesiyle birlikte, güçlülere karşı ayakta durma savaşını anlatır. Savaş esnasında ailesiyle birlikte köyün muhtarı olan Cımbıldak Hüsnü ve kurul üyesi olan Haceli ile sürekli bir çatışma halinde olan Irazca, bir türlü arzu ettiği huzuru bulamaz; çünkü Fakir Baykurt'un romanlarındaki "köylerde ekonomik temele dayalı bir varsıl-yoksul çatışması görülür. Varsillar genellikle devlet güçlerini de arkalarına alarak yoksul köylü üzerinde hakimiyet kurmaya” (Şahin, 2006:107) çalışırken; yoksullar, tıpkı Irazca'nın Dirliği’nde olduğu gibi "köy muhtarı, köy kurul üyesi, jandarma onbaşı vb." devletin gücünü elinde bulunduranlar tarafindan sindirilerek kaçmaya ve/ya boyun eğmeye zorlanırlar. $\mathrm{Bu}$ sebeple, romanın sonunda üzerindeki baskıya dayanamayan Irazca, kaderini yaşamak üzere köyünde kalırken; tüm ailesi Bayburt'a taşınarak yeni bir huzur arayışına girer. Dolayısıyla her ne kadar ailesini, 
kendi köyünde, huzur içinde bir araya tutmaya çalışsa da oğlu, gelini ve torunlarının Bayburt'a göç etmesi, Irazca'nın dirliğinin tamamen bozulduğunu gösterir.

\section{2. İsimden İçeriğe}

Eserde, tamlayan durumundaki "Irazca'nın" ve tamlanan olarak kullanılan "Dirliği" sözcüklerinin bir araya gelerek oluşturduğu isim tamlaması başlık olarak kullanılır. Aynı zamanda romanın başkişi olan Irazca, "Raziye" isminin zaman içerisinde ses değişimine bağlı olarak "Iraz" olarak kullanımıyla karşımıza çıkar. Buradaki "-ca" eki, eser içerisinde ismi geçen "Sultanca" ve "Fatmaca" örneklerinde olduğu gibi bölge kadınlarının bazılarının isimlerinin sonuna getirilen bir ektir. Iraz'ın ilk anlamı, "boyun eğen, kabul eden, rıza gösteren"dir. Ayrıca, Anadolu coğrafyasında "toprak" anlamına da gelen bu isim, "toprak ana" ile bağdaştırılır.

Genellikle doğan kız çocuklarının güçlü bir karaktere sahip olmasını isteyen ailelerin tercih ettiği bir isim olan Iraz (Irazca), romanın başkişisi düşünüldüğünde, düşmanları tarafından gördüğü baskıya karşı dik bir duruş sergileyerek (tüm ailesinin Burdur'a kaçmasına rağmen) toprağından kopmayı kendisine ve atasına bir saygısızlık olarak gören bir karakter olarak karşımıza çıkar. Yaşama kaynağı olarak benimsediği toprağının başında duran Irazca'nın boyun eğdiği ise, yurdunda kalarak -başına ne gelirse gelsin- kaderini yaşamaktır. Yani Irazca'nın razı olduğu, aslında kendi kaderidir. Bunun dışında zaten güçlü Anadolu kadını görüntüsü çizen Irazca, dirliğini koruma arzusundadır.

"Yaşayış, düzen, sağlık, varlık, geçim, huzur” anlamlarına gelen “dirlik” sözcüğü, çalışmanın tamamına bakıldığında görülecektir ki, Irazca'nın uğruna savaştığı tek değerdir. Irazca, kendi toprağında düşmanlarından arınarak ailesiyle birlikte bir düzen içerisinde, sağlıklı, varlıklı, geçim sıkıntısından uzak bir huzurlu birlikteliğin sağlanabilmesi için olayın başından sonuna kadar savaşır. Ne var ki Bayram'ın hastanelik edilmesiyle "sağlık", düşmanlarının oyunları ve toprağın yeterli mahsul vermemesiyle "varlık ve geçim", ailesinin Burdur'a gitmesiyle "yaşayış, düzen ve huzur" kavramlarını hepten yitiren Irazca, isminin birinci anlamına gönderme yaparcasına kaderine boyun eğer ve toprağında kalarak çileli hayatına devam eder.

Romanın iki sözcükten oluşan başlığı üzerinden isim analizi yapıldığında, isim ve içerik arasında derin; aynı zamanda sıkı bir bağ olduğu anlaşılır. Fakir Baykurt'un, tüm eserlerinde olduğu gibi başlıktaki ipuçlarından hareketle içerik hakkında bilgi vermeyi amaçladığı Irazca'nın Dirliği romanı, henüz eserin başında olay hakkında okurun zihninde önemli çağrışımlar yaratır.

\section{Bakış Açısı ve Anlatıcı}

Irazca'nın Dirliği romanı, hakim bakış açısıyla anlatılır. Anlatmak istediği olayları ve kişileri istediği kimliğe büründürerek eserine yansıtan yazar anlatıcı, "kendisi tarafindan resmedilen dünyanın dışındadır. Bu dünyanın tümünü daha yüksek ve nitel olarak farklı konumlardan" (Bakhtin 2001:351) çözümler.

Olayın geçtiği ana mekanı anlatarak romanına başlayan yazar, henüz eserin başında, hakim (yazar) anlatıcı oluşunun verdiği niteliği kullanarak Karataş’ın genel özelliklerini anlatir:

“Türkiye'nin kırk bin köyünden biridir Karataş. Dört yanı dağlarla çevrilidir. Kırk bin köyün içinde güzellikte, yoksullukta, geçimsizlikte birinci...” (Baykurt 2010:1)

Hakim anlatıcı olan yazar, "nakledilmek istenilen itibari alem ile ilgili her şeyi bilen ve gören” (Aktaş 2000:88) bir bakış açısına sahip olduğu için yaşanılan olayların tasviri 
kadar, karakterlerin bilinçaltının dışavurumu olarak da kendini hissettirebilir. Burada yazar, karakterlerin özelliklerinin farkında olandır ve anlatıcısıdır. Bu bağlamda, ana karakterlerin ruh hallerini de aktaran hakim anlatıcı; Kara Bayram'ın, Ahmet'in başına gelenleri öğrendikten sonra sinirine hakim olamayarak oğlu Kara Ahmet'i dövdüğü anı ve bunun üzerine babasından korkan Ahmet'in ruh halini şöyle ifade eder:

"Babası bağırınca, Ahmet, kurbanlık koyun gibi uysal oluyor; gözleri buğulanıyor, yüzü ağlayacak gibi geriliyor. Ondan sonra 'herr' deseler ağlar” (Baykurt 2010:111)

Hakim bakış açısıyla eserini kaleme alan yazar tanrısal bir nitelik olan her şeyi bilme özelliği ile Irazca örneğinde olduğu gibi tüm kahramanların akıllarından geçeni okur ve okuyucuya sunar:

'Yattı yatağa, yeniden beklemeye başladı. 'Uyur kalırsam!?' diye korkmadı. 'Gece yarıyı geçer geçmez uyanır, inerim; yaparım yapacağımı!...' dedi. Ama uyanmadı. Bin tepede, milyon derede geziyor aklı. Ufacık bir umut arıyor. 'Gitmez de cayar mı? Cayarsa bağışlar mıyım? Bayram'ı asla bağışlamam! Kara Bayram'ı1ı asla!... Haçça Gelin'i iki üç gün sıkar, ondan sonra bağışlarım. Çocukların cezaları birer gün olur..." (Baykurt 2010:258)

Hakim bakış açısıyla kaleme alınan Irazca'nın Dirliği isimli romanda yazar, roman boyunca kahramanların fiziksel ve ruhsal betimlemelerini yaparken, romanın çeşitli yerlerinde kahramanları diyalog yoluyla konuşturmayı da ihmal etmeyerek onlara söz hakkı verir. Ayrıca hakim anlatıcı, söz konusu özelliğinin verdiği sınırsız imtiyazla Irazca'nın Kara Şali ile birlikte olduğu dönemleri anlattığı gibi sürekli geçmişe dönüşler yaparak, geçmiş ile olayın yaşandığı zaman arasında bağ kurar.

Romanın anlaşılabilirliğini artırmak ve karakterlerin iç dünyasını okuyucuya sunarak olaylar arasında sebep-sonuç ilişkisi kurmak amacında olan hakim (yazar) anlatıcı, gören durumunda oluşunun sunmuş olduğu imkanlardan yararlanır. Üçüncü tekil kişi anlatıcı konumundaki yazar, böylece karakterlerin iç dünyasına girerek kafasındaki okur ve olayların gelişimi hakkında önceden yol gösterici haberler verir. Bu yönüyle okuyucuya çok fazla yorum yapma imkanı vermeyen hakim (yazar) anlatıcı, olaylar arası düğümleri de tek tek kendisi çözerek sonuca gider.

Değindiği toplumsal bir sorunu ele alarak bunu bir takım sebeplere dayandıran yazar anlatıcı, üçlemesinin ikinci romanı olan Irazca'nın Dirliği'ni de tezli roman olarak karşımıza çıkarır. Aktardığı sosyal konuların tümünde hakim anlatıcı oluşunun gereği olan görünmezlik ilkesine sadık kalan Baykurt, tezini karakterler arası diyaloglarla okuyucuya sunar ve anlatının hiçbir yerinde kendini açıkça belli etmez.

Yazar anlatıcı, her ne kadar tarafsızlık ilkesine sadık kalmaya çalışsa da -gelenekçi yazar olmasından dolayı- tezini savunmak için yer yer Irazca'yı düşmanları karşısında yüceltir. Buna rağmen, hakim anlatıcı olduğundan karakterlerin diyaloglarından çıkarımlarda bulunmaz; bunları okuyucuya bırakır.

Olayı anlatırken gerekli psikolojik gerilimi sağlayan yazar, karakterlerin verdiği tepkilere şaşırmaz. Bu yönüyle Irazca'nın verdiği tepkiler ya da Kara Bayram'ın Bayburt'a kaçması için gerekli zemini hazırlayan yazar; karakterlerine rollerini benimsettiğini gösterir.

Romandaki gerilim ve aksiyon sayesinde romanı ölü doğmaktan kurtaran yazar, anlatının sonuna kadar gizin korunmasını sağlayarak düğümlerin çözülmesini olayın sonuna -hatta üçlemenin son romanı olan Kara Ahmet Destanı'na- bırakır. 
Anlatının içine doğrudan dahil olmayan hakim (yazar) anlatıcı, romanın sonuna kadar anlatının gizini korumasını biraz da nedensellik ilkesine borçludur. Olay Örgüsü başlığı altında detaylı olarak görüleceği üzere, tüm vaka halkaları ve bölümleri oluşturan olaylar, iç içe geçmiş bir bütün misali sebep-sonuç ilişkisine dayalı bir bağlılık arz eder.

\section{Olay Örgüsü}

Birden fazla olayın birbiriyle iç içe geçerek bir bütünlük arz etmesiyle oluşan olay örgüsü, genellikle bir sebep-sonuç ilişkisine bağlıdır. Neticeli olayların oluşturduğu vaka halkalarının da kendi içinde bütünlük kurmasıyla tümel bir anlatı haline gelen romanın "çerçevesi ne kadar büyük ve ne kadar çeşitli unsurlardan meydana gelmiş olursa olsun, tutarlılık önemlidir; çünkü tutarlılık, parçaların bütün içinde uyumu, tekniğin amaca uygunluğu” (Stevick, 2004:122) anlamına gelir ki, "olay örgüsünün içerdiği tutarlılı, onun düzenlenmiş olmasından kaynaklanır; $b u$ düzenlenmiş olma da onun tamamlanmışlı̆̆ını ve bütünlüğ̈̈n̈̈̈” (Ricoeur, 2007:89) gösterir.

Cumhuriyet sonrası dönemde genellikle yoksulluk merkezli sınıf çatışmalarının kurgulandığı eserlerin çıkış noktası olarak Moran, şu ifadelere yer verir: "Anadolu romanında göze çarpan ilk özellik eylem (aksiyon) öğesinin egemen olması. Ezen/ezilen çatışması üzerine kurulmuş olan bu romanlarda, eylemin, karakter ve düşün öğelerinden daha önemli rol oynaması doğaldır. Üstelik bu bağlamda 'ezmek' fiili yönetici ve zengin sınıfin genel anlamda halkı sömürmesi dışında, kaba kuvvete dayanarak yapılan hareketleri, yani şiddeti (dayak, işkence, adam öldürme) içerir." (Moran, 2002:315) Aynı toplumsal izlekler çerçevesinde oluşan Irazca 'nın Dirliği, kırk altı bölümden oluşur.

Olay örgüsünü anlatırken eserin bütününün, sebep-sonuç ilişkisi bağlamında değerlendirilebilecek oluşunu gösterebilmek için romanı, dört vaka halkası halinde incelemek mümkündür:

Birinci vaka halkası:

-Irazca'nın, Kaymakam Orhan'ın da yardımıyla ev yeri konusunda Muhtar Cımbıldak Hüsnü ve Haceli’ye karşı üstün gelmesi; Bayram'ın düşmanlarıyla barışması,

-Neşesiyle düşmanlarını çatlatan Kara Ahmet'in, Deli Haceli'nin evinin önünden geçerken sanki Fatma için söylüyormuş gibi Merdine de deli gönül merdine türküsünü söylemesi ve Fatma'nın da kendi kendine bu türkünün devamını getirmesi,

-Irazca'nın dirliği ev içerisinde devam ederken Irazca ve Bayram'ın bişi muhabbeti yapmas1,

-Deli Haceli'nin Bayram'dan intikam almak için plan yapması,

-Ahmet'in, öküzle ineği Kır Bağları düzlüğünde bırakıp öteki gütmecilere doğru yürürken kadınlarla karşılaşması ve kısa süren sıkıcı bir sohbete dahil olması,

-Bayram'ın çocukları okutma fikrini Haçça'yla paylaşması ve sonrasında fasulyeleri sularken Fatma' yla karşılaşması,

-Ahmet'in, kadınların yanından ayrıldıktan sonra Deli Haceli’nin biraderi Boz Ömer ve Muhtar Hüsnü'nün oğlu Cemal ile karşılaşması ve kırda birlikte yemek yemesi,

- Fatma ve Bayram'ın uzun zaman sonra, kendirlerin içinde tekrar birlikte olması.

İkinci vaka halkası:

- Ömer'in öç almaya yönelik plan yapması ve Ahmet'e sidikli su içirerek, tecavüz etmeye çalışması, 
- Ahmet'in, başından geçenleri annesine anlatması,

- Haçça’nın, oğlunun başından geçenleri Irazca ile paylaşması,

- Irazca'nın olayı öğrendiği geceyi uykusuz geçirmesi,

- Ahmet'in olayların etkisiyle hastalanması,

- Boz Ömer'in, Ahmet tarafından boğazına atılan bıçak izini yengesinin yazmalarından biriyle sararak gezmesi,

- Muhtar Cımbıldak Hüsnü'nün traktör alma planı yapması,

- Ahmet, Irazca ile birlikte tarlaya giderken yolda Cemal ile karşılaşması ve Cemal'in Ahmet'e sataşması,

- Köylünün, Ahmet'in başından geçenleri öğrenmesi ve Sultanca'nın konuyu ablası Irazca ile tartışması,

- Muhtar'ın, traktörü kullanması için oğlu Cemal'i ikna etmesi.

Üçüncü vaka halkası:

- Kara Bayram'ın olayı öğrenmesi ve Kara Ahmet'i kanlar içinde kalıncaya kadar dövmesi,

- Irazca'nın telkinleri sonucu Bayram ve Ahmet'in karakola dahi uğramadan Kaymakam Orhan'a gitmek için yola koyulması,

- Kaymakam'a Irazca’nın selamını götüren Bayram'ın ve oğlu Ahmet'in kaymakam tarafından ilgi görmesi ve yönlendirilmesi,

- Kaymakam'ın girişimiyle savcının devreye girmesi sonucu Boz Ömer ve Cemal'in tutuklanmas1,

- Haberi öğrenen Irazca'nın beyazlar giyinip kınalar yakması,

- Tahsildar Yunus Efendi, köylüden vergi toplarken kimsenin verecek gücü yokken Irazca'nın evdeki unu satarak hükümete karşı vatandaşlık görevini yerine getirmesi,

- Haceli ve Cımbıldak Hüsnü'nün Kaymakam, Onbaşı ve Reis Bey ile görüşmesi,

- Muhtar'ın Kara Bayram'ı davasından geri çevirmeye çalışması ve Bayram'ın kabul etmemesi sonucu Muhtar ile anlaşan Onbaşı'nın Kara Bayram'ı karakola çağırması,

- Karakola giden Bayram'ın Onbaşı tarafından azarlanması ve tuzağa düşürülerek davasından vazgeçtiğine dair dilekçeyi imzalaması,

- Boz Ömer ve Cemal'in tutukluluklarının sona ermesi sonucu köye dönerek Kara Bayram ve ailesiyle kavgaya tutuşması; Kara Bayram'ın öldüğünün sanılması,

- Kara Bayram'ın at arabasına atarak hastaneye yetiştirilmeye çalışılması,

- Ahmet'in olanlardan etkilenerek saklanması ve annesi Haçça'nın Ahmet'i bulması,

- Erle Karakolu'ndan yardım isteyen Irazca'nın, Onbaşı'ndan yardım alamaması ve ilçeye doğru at sürmesi,

- At arabası ilçeye vardıktan sonra Irazca'nın Kaymakam'dan yardım istemesi ve Kaymakam'ın kendi özel aracıyla Bayram'ı il hastanesine göndermesi,

- Bayram ile özel olarak ilgilenen Kaymakam'ın, Irazca'ya Oğlun kurtuldu haberini vermesi ve Muhtar'ın pişman kişi rolüne bürünmesi, 
- Bayram hastanedeyken dahi ekini yerde bırakmamayı düşünen Irazca'ya köylünün yardım etmesi,

- Irazca'nın Bayram’1 görmek için tekrar Burdur yolunu tutması,

- Kosa ve Ağali'nin Melek Hasan’1 kandırarak Muhtar'ın yolunu kesmesi ve Muhtar'a bayıltana kadar işkence etmesi,

- Burdur'a giden Irazca'nın oğlu Bayram’ın iyi olduğunu görmesi ve tekrar Karataş’a dönmesi,

- Kaymakam Orhan'ın sürgün edilme haberini almasının ardından bu haberi paylaşmak ve helalleşmek için Irazca'ya gelmesi.

Dördüncü vaka halkası:

- Hastanede işgören olarak çalışan Navrumlu Ali ile tanışan Bayram'ın şehre taşınma kararı alması,

- Kendisiyle özel olarak ilgilenen Doktor Ahmet'ten iş isteyen Bayram'a ve Haçça'ya, Doktor Ahmet'in girişimleri sonucu hastanede iş verilmesi,

- Karataş'a giderek şehre göç kararını ailesiyle paylaşan Bayram'ın annesi Irazca'dan ağır tepki görmesi,

- Bayram’ı kararından vazgeçiremeyen Irazca'nın daha büyük tepkiler vermesi,

- Irazca'nın, ailesinin gidecek oluşuna üzülmesi ve sabaha kadar geçip giden zamanı düşünmesi,

- Kara Bayram ve Haçça'nın tüm uğraşlarına rağmen Irazca'nın köyde kalması ve Irazca hariç tüm aile bireylerinin köylüyle helalleşerek Burdur'a gitmesi,

- Ailesi gittikten sonra sessizce oturup etrafinda olanlara kayıtsız kalan Irazca'nın, sonunda traktör alan Muhtar'ın laf atmalarına karşılık vermesi ve sadakati temsil eden köpeği Toman'ın Irazca'ya geri dönmesi üzerine Irazca'nın tekrar hayata tutunması,

- Kendileri için cehenneme dönen Karataş’tan ayrılarak Burdur'a yerleşip işlerini yoluna koyan Kara Bayram ile ailesinin, huzurlu; ancak Irazca özlemi dolu yaşantısı içinde, anne-babasının okula başlayan Kara Ahmet'ten beklentilerini dile getirip Irazca'yı da kastederek, "Oku, cümlemizi kurtar..." demesi.

Kara Ahmet'e yüklenen ağır sorumluluk, Fakir Baykurt'un üçlemesinin son romanı olan Kara Ahmet Destanı'nın yolunu açarken Irazca'nın dirliğinin bozulduğunu gösterir.

Irazca'nın Dirliği romanında, başından geçen türlü olayın ardından, "köydeki anlaşılmazlıkların arkasının kesilmeyeceğine de iyice inanması, onu, köyden uzaklaşmaya, bu tür olayların olmayacağl bir yere, 'şehre' göçmeye zorlar. Bayram, gürültüsüz bir hayat ve çocuklarını okutabileceği bir çevreyi" (Kaplan, 1993:343) isteyerek yılların yorgunluğunu üzerinden atmayı; dolayısıyla yeniden hayata tutunmayı amaçlar. Yanardağ, Kara Bayram'ın Bayburt'a göçünün, üçlemenin ikinci eseri üzerindeki etkisine şu ifadelerle yer verir: "Bayram'ın kavga sahnesinden sonra kente göçmeye karar vermesiyle romanın çatışma ögelerine bir yenisi eklenir. Köy-kent karşıtlı̆̆ı. Bayram, kendi yaşantısını düzenlerken, ister istemez Muhtar'ın ve Haceli'nin hayatının değişiminin de gerçekleşmesini sağlamış olur. Yani Irazca'nın dirliği bozulur. Irazca için yıkım, dışardan değil, içerden gelmiştir." (Yanardağ, 2005:278) Bu durumda amacına ulaşamayan başkişi Irazca, tinsel tükenişin simgesi olmaktan öteye geçemeyerek, üçlemenin son romanında, birinci dereceden karakter özelliğini Kara Ahmet'e bırakır. 
Konuyu oluşturan olaylar dizisinin, birbiriyle bağlantılı olarak dört vaka halkası oluşturduğu romanın sebep-sonuç ilişkisine dayalı gelişimi, okuru romanın iç dünyasına çeker. Romanda sebep-sonuç ilişkisine dayalı, "bu bütünselliğin özünü, başlangıç ve son arasında" dengede durma çabasında olan birey oluşturur; "ama roman tam da bireyi yalnızca bu şekilde içerebildiği için, birey salt bir araç haline gelir ve yapıttaki merkezi konumu da hayatın belli bir sorunsalını açığa çıkarmaya” (Lukacs 2011:89) yarar. Böylece yazar, hayatın kendisinden ödünç aldığı olayın konusu ve karakterleriyle okura "yabancı olmayanı" sunarak olaylar arası bağlantıların kurulmasında sistematik, aynı zamanda gelenekçi bir yol izler. Gasset'in, köy romanı yazarlarına yönelik telkin ettiği "yazılanlar, romanköye götürmelidir onu(okuru)" ve "her okuru bir taşrallya dönüştürmek" (Gasset 2012:85) sözleri; okuru, romanın sınırları içine hapsedip olaylara derinlik kazandırma amaçlıdır.

Romanın bugün dahi ilgiyle okunması, bahsedilen hapsedilmenin/içselleştirmenin sonucudur. Bu durum, anlatılan dönemden uzaklaşılmış olunsa da romanın gerçekliğini yansıtır. Romanın gerçekliği, insanın bilinçaltının sürekli bazı konular üzerine çatışma halinde olduğundan, kurmaca üzerine de kurulu olsa, okurun olay içinde kendinden bir şeyler bulmasına ya da kendini herhangi bir karakterle özdeşleştirmesine neden olur. Bu durum ise estetik bir haz uyandirarak, okuyucuyu sonlu olandan sonsuz olana iter.

\section{Zaman}

Romanda tüm olayların, kurgusallığın içselleştirilebilmesi için, belli bir zamana ihtiyacı vardır. Roman incelemesinin yapılabilmesi için üç tür zamanın göz önünde bulundurulması gerekir: "birincisi hikayenin, ikincisi yazının, üçüncüsü de okumanın" (Baldıran, 2002:122) zamanıdır. Vaka zamanı ile nesnel zamanın aynı dönemde buluştuğu ve yine aynı dönemde yazıya aktarıldığı romanın hikaye/öykü zamanı, "romanda olayların geçtiği zaman dilimini” (Çetin 2011:129) kapsar. Söz konusu zaman dilimi içerisinde başlangıçta, Irazca'nın dirliğinin bozulmaması uğraşı yer alırken, bu durum son bölümde yerini, dirliğin tekrar sağlanması uğraşına bırakır. Irazca'nın Dirliği romanında zaman, Cumhuriyet dönemi sonrasını kapsar. Dönem içerisinde Necip Bey’in çiftliği durumunda olan Karataş, Necip Bey'in şehre taşınmasından sonra köylüye kalır. Asıl olay bu zamandan sonra başlar ve kesin tarih roman içerisinde belirtilir:

“Necip Bey, 1950’lere kadar Karataş’ın evini damını, atını, itini, suyunu, sudan uslu halkını tepe tepe kullandı." (Baykurt 2010:1)

Olayın yıl içerisindeki mevsimini belirten yazar havanın sıcak oluşu, ekinlerin biçilme zamanının gelişi gibi anlatılarıyla, okuyucuya, olayın yaşandığı ay hususunda ipuçları verir. $\mathrm{Bu}$ ay, olayın yaşandığı Burdur ilinin bulunduğu coğrafya ve olayın tarihi düşünülecek olursa Mayıs ayıdır:

"Bahar söktü geldi gene. Yaz basıyor. Sıcaklar yakar oldu. Ekinler sarardı, bir uçtan gevriyor. Arpalar erişti. Peşine düşüp biçmek gerek. Karataşlı köylülerin içine orak tasası çöktü.” (Baykurt, 2010:6)

Romanın genelinde kronolojik bir zaman dilimi kullanılırken gün içerisinde vakitten de haber verilir:

"Gün öğlen ile ikindinin arasında.” (Baykurt, 2010:18)

Cemal ve Boz Ömer ile kavga eden Bayram hastaneye yattıktan bir zaman sonra kendine gelir. Irazca, Bayramı ziyarete gittiği zaman oğlunun hastanede ne kadar zaman kalacağını öğrenir. Bu süre Bayram'ın Karataş’1 terk edeceği günün habercisidir; çünkü 
Bayram geçecek olan iki aylık zaman diliminden sonra şehre yerleşmek üzere, Irazca hariç, ailesiyle birlikte şehre yerleşir. Bayram'ın, Irazca'nın ziyaretinden sonra hastanede kalacağı süre ise şöyle belirtilir:

"Bana kalsa hemen şu dakika çıkarım gözel anam! Ama daha durumum iyi değil. Doktor Ahmet Bey diyor, 'senin kafada kafa denecek hal kalmamış Bayram Kara! Uğraşıp çalışıp yeni bir kafa yapacağız sana!' Onun için, benim burada yatmam, daha epey sürer. En aşağı iki ay! Ahmet Bey, 'İki ay yatarsın!' diyor.” (Baykurt 2010:225)

Romanın genelinde olaylar kronolojik olarak anlatılsa da özellikle Irazca'nın Kara Şali dönemini hatırlaması ve hatırlatması zamanı; ana konu dışında, akronik hale getirir. Olayın yaşandığı tarih ile yazıldığ 1 tarih iç içe olduğu için anlatıcı, eser içerisinde olayın yaşandığ1 mevsim gibi, gün içerisindeki vakitlerden de kesin olarak bahseder.

Roman içerisinde zaman kavramının belli bir düzen içerisinde devam etmesi ve olay zamanı ile okuma zamanı arasındaki boşluğun çok uzun olmaması okurda gerçeklik algısı yaratır. Olayların gerçek zamanının da açıkça belirtilmesi bir anda olayın içinde kendini bulan okurun, bilinçaltında olayı kendi zaman şartlarında tekrar yaşamasına sebep olabilirken, bu durum zamanın gerçekliği ile doğrudan ilgilidir.

\section{Mekan}

Yapısal bakımdan romanın ana unsurlarından biri olan mekan, "insan varoluşunun konumlandiğl yer” (Korkmaz, 2015:77) olarak tanımlanır. Bu bakımdan Irazca'nın Dirliği romanında mekan; çevresel ve algısal mekan olmak üzere iki ana başlık altında incelenebilir:

\section{1. Çevresel Mekan}

Çevresel mekan; sınırları görülen ya da tasvir edilen alanın dışına çıkamayacak biçimde romanda yalnızca topografik yönden bahsedilip, üzerinden geçilen yer olarak tanımlanabilir.

Irazca'nın Dirliği romanında olaylar, Burdur ilinin Karataş köyünde başlar. Irazca ve Irazca'nın ailesi, Karataş'ta sürekli muhtar ve Haceli ile çatışma halinde olduğu için Karataş sınırları dışına da çıkan mekan, genel olarak Karataş'ın bulunduğu Erle Çukuru, Karataş'ın kırları, Değirmen Deresi, Yeşilova ilçesi ve Burdur ili gibi mekanlara yayılır.

Mekanın gerçekliği, olayların anlaşılırlığını artırırken okurda, roman içerisinde yer edinme hissi oluşturur. Ayrıca, çevresel mekanların ayrıntılarıyla tasvir edilmesi, yazarın olayın anlatıldığı mekanlarda gerçek gözlemlerinin sonucudur.

\subsection{Algisal Mekanlar}

\subsubsection{Kapalı/Dar ve Labirentleşen Mekanlar}

Karakter, "ayă̆ının bastı̆̆ yeri kendi bilinç düzeyine ve algllama biçimine göre" (Şahin, 2007:193) kavrayarak mekanı içselleştirir. Bulunduğu yer içindeki konumuna göre varlık alanını oluşturabilen karakter, çevresel mekanlara algısal değerler kazandırarak olayın sosyal ve psikolojik yönünü de ortaya koyar. Böylece çevresel etmenlerin dolayısıyla nesnelerin- göründüğünden farklı bir nitelik kazandığı romandaki mekanlar üzerinde anlamsal bir derinlik ortaya çıkar.

Irazca'nın Dirliği romanında mekanların, karakterler üzerindeki yoğun etkisi açıkça görülür. Roman içerisinde karakterlerin, başlangıçta huzur bulduğu ortamlar dahi sonradan kapalı/dar mekana dönüşür. Zaten bu tür mekanlarda, "fiziksel boyutlar değil, anlatı karakterlerinin o andaki ruhsal durumu, bağlamı ve mekanı nasıl algıladı̆̆ı” (Korkmaz 
2007:401) algısallığı belirler. Örneğin, Irazca'nın evi, torunları evin içinde neşeyle oyalanırken, açı/geniş mekan konumundayken, ailesini derinden sarsan olaylar ve bu olayların devamında çok sevdiği ailesinden uzak kalışı sebebiyle kendisiyle baş başa kalan Irazca için kapalı/dar mekana dönüşür:

"Her gün böyle: Sabah kalkıyor, dışarı çıkıyor. Merdiven başındaki direğin dibinde yaslanıp oturuyor. Çıt çıkarmadan, uzun uzun köyün içine bakıyor, gözünü cami çeşmesinden ayırmıyor. Aklına yemek içmek gelmiyor. Ağzına bir kuru lokma koymadan akşamı ediyor. Gelip gidene, laf atana, soru sorana karşılık vermiyor. Dili alınmış gibi. İçinde denizler yuvarlanıyor. Öfkesi durmadan kabarıyor, azıyor. An oluyor ağlamak; an oluyor, haykırmak istiyor. Eline bir balta alıp köy içine çıkmak, çeşme başına durmak, geleni geçeni yaralamak istiyor. Kırmak, dökmek, taş üstünde taş koymayıp dağıtmak istiyor." (Baykurt 2010:271)

Irazca'nın bu halleri yok olan dirliğiyle birlikte gelen bir başkaldırının ürünüdür. Yıllarca dirliğini korumak gayesinde olan Irazca, kocasının ölümünden sonra yalnızlığı hiç yaşamamışken, bir anda evinde tek başına kalır. Bunun üzerine ontolojik bağlamda da bir bunalıma sürüklenen Irazca için başta evi olmak üzere, tüm Karataş kapalı/dar mekana dönüşür.

Irazca ve ailesinin yaşadıkları da düşünüldügüunde "mekan, varoluş kaygısıyla ilgili bir duraksamadır; zamanin sonsuz akışında yitip gitmek istemeyen insanin tutunduğu 'dışardaki içerdelik' niteliğinde bir yer' (Korkmaz 2007:401) olarak karşımıza çıkar. Fakir Baykurt'un üçlemesinin ilk romanı olan Yllanların Öcü'nde, ev yeri sebebiyle düşman edinen Irazca, torunu Kara Ahmet'in başına gelen olaylarla birlikte hepten huzurunu kaybeder. Öyle ki bu olaylardan sonra Cımbıldak Hüsnü, Deli Haceli, Cemal ve Boz Ömer Irazca'nın ailesine huzur vermez. Artık onlar için, Karataş'ın her yeri kapalı/dar mekana dönüşür. Özellikle Boz Ömer'in Cemal ile anlaşarak Değirmen Deresi'nde Ahmet'e kurduğu tuzak sonrası, başta Değirmen Deresi olmak üzere tüm Karataş, Ahmet ve ailesi için kapalı/dar bir mekan halini alır. Ardı arkası kesilmeyen olaylar sonrası doğru yönü bulamayan Kara Bayram, ailesini de alıp Burdur'a yerleşerek içinde bulunduğu kaotik ortamdan kurtulmayı planlar. Ancak bu kaçış da çözüm olmayabilir.

Toprağından uzak kalan bireyler, gidilen/kaçılan yerde aradıkları huzuru bulamazsa bu bireyler yine kendilik değerlerinden uzak olarak kapalı/dar mekanın tutsaklığını yaşamak zorunda kalır. Bencil insan tipinin örnekleri olarak, Irazca'nın ailesinin yitimi için uğraşan karşı değerler Fakir Baykurt'un eserinde birer sembol olarak aslında insanın varoluş savaşının en büyük tehdidini oluşturur. Bunun sonucu olarak, Kara Bayram ve ailesi, bencil olan karşı değerlerin baskısı altında, kendilik değerlerinden uzak bir yaşam sürmek zorunda kalabilir; aksi halde bir grubun art niyetli bencilliği yüzünden, "doğal veya kültürel düzlemde tahrip edilen bir değer dizgesinin yerine, bütün zamanlar boyu aynı kodda bir yenisini koymanın imkanı yoktur." (Korkmaz 2015:367). Bu sebeple, bencil yönüyle fiziksel ve ruhsal anlamda Irazca ve ailesinin çöküşü için olayın başından sonuna kadar uğraşıp kötülüğü temsil eden kart karakterler algısal bağlamda mekanı, kapalı/dar bir hale büründüren faktörler olarak ortaya çıkar. Ancak varoluş savaşı veren Kara Bayram için kapalı/dar mekan, Karataş Köyü ile sınırlı kalmaz. Kara Bayram için kaotikleşen bir diğer bunalım mekanı ise Jandarma Karakolu'dur. Onbaşının Kara Bayram'a karşı tavırları, Kara Bayram için Jandarma Karakolu'nun kapalı/dar mekan olarak algılamasına sebep olur:

"Jandarma Karakolu (...) Bağırıp çağırarak bir zaman konuştu sert. Elini yumruk yapıp masaya indirdi birkaç kez. Bir türlü yatışmadı. Bayram, yüreği körük gibi bekledi. Arada 
bir karşılık verecek oluyor, Onbaşı'dan firsat bulamıyor. Onbaşı hızlı hızlı, 'Namussuzlar, nankörler!...' diye bağırıyor." (Baykurt 2010:162)

Önceden de güvenmediği Onbaşı’ya karşı, bu tavırları sonrası hepten güveni kaybolan Bayram, Onbaşı'ya karşı koyamaz ve Cemal ile Boz Ömer'e olan davasından vazgeçtiğine dair hazırlanan kağıdı, okuma bilmemesinden faydalanan Onbaşı karşısında imzalayarak, bir nevi geçmişin kapalılığının geleceğe taşınacağının da senedini yapmıştır.

Roman içerisinde karakterlerin bilinçaltı hareketlerinin ve bulundukları yeri algılayış biçimlerinin ayrıntılarıyla yansıtılması, yazarın hakim anlatıcı konumunda oluşunun sonucudur. Yazar için mekanların, olayın yaşandığı konum durumundan fazla bir anlam ifade etmesi, roman karakterlerinin mekanı içselleştirmesine sebep olurken bu durum okura da yansır. Olayların anlaşılabilirliğini artıran bir unsur olarak değerlendirilen mekan algısallığ 1 , karakterlerin yanı sıra mekanların da birer ruhunun olduğuna işaret eder. Irazca'nın Dirliği romanına bakıldığında ise, genelinde kişiler ve gruplar arası çatışmanın yer aldığı eser, kapalı/dar mekanların yoğun bir biçimde işlenmesine sebep olur.

\subsubsection{Açık / Geniş Mekanlar}

Roman karakterinin kendisini iyi hissettiği açık/geniş mekanlarda kişiler, "kendisiyle, çevresi ve bütün evrenle uyuşum içindedir. Kapalı ve dar mekanlar nasıl çatışma mekanları ise, açık ve geniş mekanlar da uyumun ve huzurun" (Korkmaz 2015:93) mekanları olarak karşımıza çıkar. Karakterler, kendilik değerlerini koruyabildikleri ve diledikleri huzura sahip olabildikleri ölçüde olay içerisinde düğümün çözülebilmesi için kilit kararları genellikle bu tür mekanlarda alırlar.

Irazca ve ailesi için Kara Ahmet'in başına söz konusu olaylar gelmeden önce evleri açık/geniş mekandır. Bachelard'a göre, “evde, her şey farklılaşır, çoğalır.” (Bachelard 2013:71) Kişinin, dış dünyanın sınırlarını aşarak yeni bir düşlemin içine girdiği ev; anlatıda, içtenlik mekanı olarak karşımıza çıkar ve içindekilere huzur verir. Karakterler için, "sahip olduklarl tikel değerlerin tümünü temel bir değere katmaya çalışarak, evi hem birliği hem de karmaşıklığı ele almak koşuluyla iç uzamın mahremiyet değerlerinin fenomenolojisini inceleyebilmek açısından evin ayrıcalıklı bir varlık olduğu" (Bachelard 2008:37) yadsınmaz bir gerçektir. Bu bağlamda, Kara Ahmet'in evin içinde yaptığı taklitler tüm ailenin yorgunluğunu, her ne kadar çalışsalar da alır götürür ve aileyi zinde tutar:

"Buzağı taklidi yapıyor. Kara buzağının hem sağılan hem çifte koşulan anası Aymelek'e sokuluşunu, süt diye çırpınışını, buruşuk, boş memeleri çekiştirerek emişini yapıyor; gülmekten kırılıyorlar. Kasıkları acıyor hepsinin...” (Baykurt 2010:4)

Deli Haceli'nin karısı Fatma, Bayram'a ezelden yanıktır. Kara Bayram ile uzun zaman sonra kırlarda karşılaşır ve kendirlerin arasında birlikte olur. Bu birliktelik hem Kara Bayram hem de Fatma için kendirlerin arasının açık/geniş mekan olmasını sağlar. Fatma, mutluluğunu söz konusu mekanda yüksek sesle dile getirmekten çekinmez:

“'Duysun kocaman kulakların, hiç kimseden korkmuyorum!' dedi Fatma. 'Korkanlar da ölecek! Cihan duysun! Bunca tadı vardı bu işin, bir erkekle kancık, bir kökte bitmiş gibi bir olabiliyordu da neye benim haberim olmamış? Çok şükür bunu da tattım! Bin şükür, burda, hoş kokulu kendirlerin arasında tattım; hemen ölsem gam yemem!” (Baykurt 2010:37)

Yıllardır Kara Bayram'ın hasretiyle dış dünyaya kendisini kapatan Fatma, her akşam farklı bahanelerle kocasından kaçar. Bir anlamda, dünyalık zamandan kendisini uzaklaştıran Fatma, Kara Bayram'la birlikte olduğu güne kadar, kendi iç dünyasındaki 
düşlerle yaşarken o günden sonra bulunduğu her ortamı açık/geniş mekan olarak görecek ve öyle yaşayacaktır. Mekanı içselleştirerek, ona yeni anlamlar kazandıran kişi burada, aslında kendi düş dünyasında olanı hayatına kazandırır. Öyle ki, "hayat ve ölüm arasında gidip gelen insan, mekanı da bu kavramlar arasında anlamlandırır. Onun için dağdan ovaya, denizden karaya, çiçekten ă̆aca, çeşmeden türbeye, mezardan eve, meydandan şehre her şey yaşamak ve ölmek açısından" (Göka 2001:97) anlam kazanır. Bu yönüyle, mekanın fiziksel koşulları ne olursa olsun, kahraman için huzur mabedi olan mekanlar, açık/geniş mekan olarak tanımlanırken; kendirlerin arası da Fatma ve Kara Bayram için söz konusu (açık/geniş) mekana dönüşür.

Mekanın içselleştiği/içselleştirildiği durumlarda karakterler, kendini daha rahat ifade edebilmekte ve daha doğru kararlar alabilmektedir. Algısal bir düzen içerisinde ele alındığında, "romanın yaratılmış gerçekliğinde görünür olan tek şey, sistematikleştirmeyi (nesnel dünyanın uzlaşımsallığını ve öznel dünyanın içselliğini vurgulayan bir sistematikleştirme) somut hayattan ayıran uzaklık" (Lukacs 2011:77) olarak kabul etmek gerekir. Bu anlamda Irazca ve ailesi için genellikle labirentleşen bir mekan görüntüsünde olan Karataş sınırları içerisinde bireysel uğraşlar neticesinde oluşturulan mahremiyet alanları, açık/geniş mekanların oluşturularak karakterlere hareket alanı sunulmasını sağlar. Düşlenene sahip olma arzusunda olan karakterler de bu sayede, vaka halkaları içerisinde yer alan düğümlerin çözümünde ve sonuca ulaşmada bir yandan yeterli zamanı kazanırken diğer yandan ruhsal anlamda kendini yenileme firsatı yakalamış olur.

\section{Kişiler Düzlemi}

Anlatım esasına dayalı metinlerde nesnelere ve duygulara anlam kazandırarak yazarın vermek istediği mesajı okura iletmekle yükümlü olan kişiler, kendilerine yüklenen karakteristik özelliklere ve olayın merkezine yakınlıklarına göre anlam bulur. Bu bağlamda, "sosyal ve psikolojik şartların yarattığı karakterler, kurmaca dünyanın çatışma zeminini ve kişiler dünyasının ruh durumunu açımlar” (Deveci 2007:85). Kişiler, böyle bir durumda hareket alanının genişliğine, olaylara yön verişine/nesnelere hükmedişine ve anlatının kurgusal boyutunun içinde konumlandığ 1 yere göre karakteristik özellikler kazanır.

Öykü zamanı ile yazılma zamanının aynı döneme ait olduğu Irazca'nın Dirliği romanı; yazarın yaşantısının bir ürünü olarak karşımıza çıkar. Bu durum, romanda anlatılan olayın olduğu kadar, olayın merkezinde konumlandırılan kişilerin de bizdenliğini sağlar. Zaten, özellikle toplumun sosyal sorunlarının yansıması olarak doğan tezli romanlarda, "kişilik kurgusunun okurda gerçeklik duygusunu uyandırması beklenir; çünkü okur, anlatıdaki kişi ve olaylarla ne kadar derin bir yaşamsal/deneyimsel băglantı kurabilirse etkilenim derecesi de o kadar yüksek" (Aşkaroğlu, 2016:316) olur. Bu bağlamda, olayın yaşandığı dönem içerisinde, yazarın kendi çevresindeki kişileri ve olayları kurgulayarak sunduğu Irazca 'nın Dirliği romanı aşağıda belirtildiği biçimde sınıflandırılabilir:

\subsection{Başkişi}

Romanda, tüm olayların doğrudan merkezinde konumlandırılan başkişiler, "iç dünyaları ve hayatları ayrıntılarla anlatıldı̆̆ından diğer karakterlerden kolaylıkla ayrılır”, ve her anlatıda yalnızca bir kişide görünen bu karakterler, "çatışma ve değişme süreci yaşayan, toplumda fert olarak varlı̆̆ını sürdüren ve tepkilerimizi sürekli olarak yönlendiren kişiler" (Korkmaz 1997:293) olarak okuyucunun bilinçaltını bir süreliğine kontrol altına alır.

Irazca'nın Dirliği romanında başkişi Irazca'dır. Cumhuriyet öncesi dönemi ve Cumhuriyet dönemini görmüş olan Irazca, güçlü Anadolu kadınının görüntüsü olarak 
karşımıza çıkar. Kara Bayram'ın anası, Kara Şali'nin karısı olan Irazca'nın karakter özelliklerinde genç yaşta dul kalışının ve çocuk, torun, ev, hayvan, tarla derken geçip giden hayatının etkisi büyüktür. Yıllar Irazca'yı kocatmış, aynı zamanda olgunlaştırmıştır:

"Irazca, bağdaş kurup oturmuştu. Elinde tespih var da çekiyor gibiydi. Yüzünde sakalı eksik. Dünyada ne kadar masal varsa hepsini bilen, çok gezmiş, görmüş geçirmiş, gezip gördüklerinin yardımıyla bilgeleşmiş eski bir Toros yörüğüne benziyor. Sesi de olgun, oturaklı." (Baykurt 2010:245)

Tecrübesiyle ve bilgeliğiyle etrafındakiler için kurtarıcı olmak isteyen Irazca; ailesinin iyiliği için uğraşan, hak yemeyen, yiyene tavır alan, ağzı dualı, kendi halinde bir birey olduğundan "ülkü değer" olarak karşımıza çıkar. "Ruhunu eserin merkezine yerleştiren yazarın benimsenmiş değerlerini, doğrularını, özlemlerini, arzularını, varlık kaygısını, kısaca anlatıcının yaratıcı ben'ini temsil eden bir varoluş dizgesi içeren" (Korkmaz 2002:273) bir ülkü değer olarak karşımıza çıkan Irazca, yazar tarafından olayın tamamında ön planda tutularak düzeninin bozulmasından kaygılanır. Bu durum başkişiyi geceler boyu düşünmeye ve düşlemeye iter. Aynı zamanda, olayların Irazca'nın etrafında şekillenmesi ve Irazca ile başlayıp, Irazca ile devam etmesi ise onun başkişi olmasının bir diğer sebebidir.

\subsection{Norm Karakterler}

Romanda, olay boyunca başkişinin etrafinda yer alarak onu dolayımlayan, tamamlayan özelliğiyle "ferdi planda en çok boyutlu olan ve en fazla derinliği olan kahramanlar" olarak kendini yansitan norm karakterlerin, "tezat yaratmak ve okuyucuyu rahatlatmak gibi görevleri olduğu kadar birinci derecedeki kahramanların kusurlarını yansitma, somutlaştırma gibi fonksiyonları” (Korkmaz 1997:298) da bulunur.

Irazca'nın dostları ve her firsatta Irazca'nın yardımına koşan Kosa ile Ağali norm karakterlerdir. Irazca'nın dolayımlayıcısı/tamamlayıcısı olan Kosa ile Ağali, her yönüyle Irazca'nın eksikliklerini tamamlamaya çalışır ve dirliğini koruyabilmesi için Irazca'ya yardım eder. Öyle ki unları biter, un verirler; intikam gerekir, muhtarı döverler; akıl gerekir, akıl verirler. Irazca'ya gerektiğinde doğruyu, yanlışı söyleyerek, onu sinirlendirme pahasına, Irazca'nın eksikliklerinin giderilmesinde yardımcı rol oynarlar. Kara Bayram'ın köyü terk etmesine de bir tarafları iyi derken, diğer tarafları kötü der; ancak Irazca'nın yalnız kalacağını düşünerek, onun da Kara Bayram'la gitmesi konusunda akıl vermeye çalışsalar da Irazca'nın inadını kıramazlar. Bayram ise gitmek zorundadır; çünkü içinde bulunduğu kaotik ortamla birlikte kuşatılmışlığından kurtulmak isteyen Bayram Burdur'a giderek varoluş sorunundan kurtulmak ister. Bunun farkında olan Kosa ve Ağali, Kara Bayram'1 durdurmak için çaba sarf etmez. Kötü gün dostu olan Kosa ve Ağali romanın başından sonuna kadar Irazca'nın ailesiyle iç içedir.

\subsection{Kart Karakterler}

Romanda, karakteri kartlaşmış/kalıplaşmış biçimde yazar tarafindan bir kez açıkça anlatılan özelliklerinin, anlatı boyunca bekçiliğini yaparak muhafazasını başarıyla gerçekleştiren kart karakterler, "yalınkat bir kişiliğe sahiptirler ve daha çok 'hedef obje'ye varmayı engelleyen karşı güç grubunda yer alırlar” (Korkmaz 1997:300); ancak bu durum, kart karakterlerin ülkü değerler dizgesinde yer almayacağı anlamına gelmez. İmgesel boyutta kalıplaşmış bir yapıya/yargıya sahip olan kart karakterler, sınırları çizili bir dönem içinde belli bir grubu temsil etme özelliğiyle tamamen o dönemin ortak malı olduklarını gösteren kültürel kodların yansıtıcısı ve aktarıcısı görevini de üstlenebilir. Bu yönüyle;

Romanın başından sonuna kadar özellik değiştirmeyen ve sürekli Irazca'nın dirliğini bozma uğraşında olan Muhtar Cimbıldak Hüsnü ve Köy Kurulu Üyesi Deli Haceli; 
muhtarın oğlu Cemal ve Haceli’nin biraderi Boz Ömer birer kart karakter özelliği gösterir. Türk romanı/romancılığında dönemler içi değerlendirmeler yapıldığında her dönemin kendine ait çok yönlülükten uzak, değişmeyen, yalın; bulunduğu an ve toplumda olumlu ya da olumsuz yönüyle huy değiştirmeksizin var olan klasik/kalıplaşmış karakterler bulunur. Toplumsal statü içerisinde sınıf çatışmasının karşı değerleri olan bu karakterler (Cımbıldak Hüsnü ve Köy Kurulu Üyesi Deli Haceli) güçlüyü temsil ederken, Karataş halkı güçsüz olanı temsil eder. Muhtar Cımbıldak Hüsnü ve Köy Kurulu Üyesi Deli Haceli Cumhuriyet sonrası dönemin birçok romanında görülen bürokrasi taciri kişileri temsil ederken; Cemal ve Boz Ömer Türk romanının serseri/kavgacı kart karakterleri olarak eserde yer alır.

Bürokrasiyi ve kaba kuvveti art niyetleri için kullanmaya çalışanların karşısında durarak olumlu/iyi yönlü kart karakterlerden olan Kaymakam Orhan Bey; maddi, manevi desteğini Irazca anasından ve onun ailesinden esirgemez; bu yüzden romanın sonuna yaklaşırken sürgün edilir. Kaymakam Orhan Bey Irazca'nın deyişiyle bu yoksul ailenin belinin direğidir. Daha nesnel bir bakış açısıyla, Kaymakam Orhan Bey aslında, bürokratik çürümeye karşı devletin bel direğidir. Ancak bürokratik çürümenin bir diğer esiri Müsteşar Bey'in ve Reis Bey'in uğraşları sonucu devleti temsil eden Kaymakam yalnızlığa sürüklenir.

Kara Bayram, Irazca'nın oğludur. Sabahtan akşama kadar yazı, yaban demeden çalışır. Bayram, çocukluğundan beri evin maddi yükünü taşıyan kişi olmuştur; ancak ağır yaralanıp ölüm ve yaşam arasında gidip geldiği zaman dahi, ölümü bırakıp yaşama tutunan Bayram, kurtulduktan sonra eşini ve çocuklarını yanına alarak hayata dört elle tutunmak ve huzur içinde yaşayabilmek için Burdur'a göç eder. Aklı kendine yetmeyen Bayram, her ne kadar roman içerisinde sıkça anılsa da Irazca'yı bir başına bırakıp, iyi niyetinden de olsa başkarakterin, olayın bütünü içinde tamamlayıcısı/dolayımlayıcısı ol(a)madığı için kart karakterin olumlu yüzünü imler.

Haçça, Bayram'ın karısı ve Irazca'nın gelinidir. Haçça çocuklarına karşı fedakarlığı, Bayram'a karşı sadakati, Irazca'ya karşı saygıyı temsil eden kart karakterdir. Haçça'nın, aslında dünyalık zamanda pek bir beklentisi yoktur. Öyle ki Burdur'a gidip duşun altında yıkanacağını bilmesine, rahat edeceğine inanmasına rağmen Bayram'a sadakatinden bir an ödün verse Karataş’ta kalacaktır.

Irazca'nın torunları Ahmet, Şerfe ve Osman evin neşe kaynakları olarak ön plana çıkar. Küçük yaşlarına rağmen dünyanın ağır yükünün altına girer ve başlarından ne tür bir olumsuzluk geçse de -evde olsun, tarlada olsun- atalarını yalnız bırakmayarak sevginin ve masumiyetin sembolü olarak roman içerisinde kart karakter görevi üstlenir.

Olayın başından sonuna kadar, Kara Bayram ve ailesini sefaletten kurtarıp, olaylardan uzaklaştırmak isteyen Doktor Ahmet ve Navrumlu Ali de olumlu yönüyle ön plana çıkan kart karakterlerdir.

Bir diğer kart karakter ise Irazca'nın bacısı olup da anlatı içerisinde ara ara Irazca'yla görüşüp iyi niyetli tavsiyelerde bulunan Sultanca'dır. Sultanca da tıpkı Irazca gibi yalnız yaşar. Kendi halinde, yaşı bir kadın görüntüsü çizen Sultanca; eser içinde çok da ön planda değildir. Sultanca'nın olay kurgusu içindeki görevi, kendi halinde yaşayan ve iyi niyetli oluşuyla ön plana çıkan bir kart karakter olmaktır.

\subsection{Fon Karakterler}

Roman içerisinde sıkça karşılaşılmayıp olayın gidişatına ve/ya sonucuna etki edemeyecek kadar görüntü düzeyinde kalan; ayrıca, başkişinin karakteristik özelliklerine ulaşamayacak kadar da asıl olayın dışında kalan fon karakterler, "romanda en az derinliğe 
sahip kişi ya da kişiler grubu" olduğundan, yalnızca, "romanın birinci derecedeki kahramanına ait sosyal ortamın daha somut bir şekilde dikkatlere sunulmasına yardımcı olurlar ve ancak o zaman ilgi çekici bir boyut" (Korkmaz 1997:300) elde ederek görüntülerini yansitabilirler.

Irazca'nın Dirliği romanında, “dekoratif unsur durumunda” (Aktaş 2000:142) olup, romanın seyrine etki edemeyen fon karakterlerin bir kısmının, olayın merkezinden uzakta, yalnız ismi geçerken; diğer bir kısmı, yalnızca "köylüler, köy halkı, komşular, köy kurulu üyeleri” gibi nitelemelerle adlandırılır.

Romanın henüz başında ismi geçen ve yalnızca köyü satıp terk ettiği söylenen Necip Bey’in yanı sıra, Beytullah Hoca, Fatma, Melek Hasan, Kara Şali, Ali İzzet, Muharrem, Mevlüt, Bekir, Halil, Havalice, Selver, Kamber, Fatmaca, Cemile, Çivi Esme, Tahsildar Yunus Efendi, Kahveci Nuri, Mehmet Ali, Şoför Hasan, Müsteşar, Başhekim, Başhemşire, Hancı Ferhat roman içerisinde başlıca fon karakterleri oluşturur. Irazca'nın Dirliği romanında an içerisinde yer alan karakterlerin, başkişi ve norm karakterler üzerinde fazla etkisi yoktur.

\section{Sonuç}

Cumhuriyet sonrası döneme ait köy romanlarıyla tanınan Fakir Baykurt; Yllanların Öcü, Irazca'nın Dirliği, Kara Ahmet Destanı üçlemesinin ikinci eseri olan Irazca'nın Dirliği'nde güçlünün, güçsüzü sömürmesine karşın; güçsüz olanın, güçlüye başkaldırısını anlatır. Bunu yaparken fedakarlık, masumiyet, sadakat, sevgi, yoksulluk gibi kavramları olgunlaştıran Baykurt, dönem içerisindeki sınıf çatışmalarından ve bürokratik çürümelerden de bahseder. Bu yönüyle roman, içselleştirilirken zamanını aşan bir yapıya bürünür.

Yapısal olarak incelenen eser; Romanın Kimliği, Ísimden İçeriğe, Bakış Açısı, Olay Örgüsü, Zaman, Mekan, Kişiler Düzlemi başlıkları altında değerlendirilerek şu sonuçlara ulaşılır:

İlk olarak ele alınan Romanın Kimliği bölümünden anlaşılacağı üzere, bugüne dek on altı baskıyla Türk Edebiyatına sunulan eser, Fakir Baykurt'un diğer romanlarında da olduğu gibi, ustaca seçilerek birbirinden farklı vasıflar yüklenen karakterlerden oluşur. Bazı karakterler ise dönemin klişe tiplerinin özelliklerini yansıtırken, "temsil ettiği tipiklik, indirgendiği belirgin özellik, taşıdı̆̆ı o tek yön, abartılı bir biçimde romanın başından sonuna kadar bütün tutum ve davranışların, eylemlerin belirleyicisi" olduğundan, karakteristik yapılarının yanı sıra birer "stereotip" (Demir 2014: 125) olarak sunulur ve okura, olayın yaşandığı dönem hakkında ayrıca bilgiler verir.

İsimden İçeriğe başlığı altında ise, bu karakterlerden romana adını veren Irazca ve başkişinin amacını belirten "dirlik" sözcüklerinin içerikle ilişkisi açıklanır. Burada romanın başlığının, rastlantısallıktan uzak, olayın bütününü kapsayıcı anlamlar içerdiği görülür. Iraz/ca ve dirlik sözcüklerinin, sözlük anlamlarının yanı sıra, halk arasında bu sözcüklere yüklenen anlam/değerler ele alındığında, yazar tarafından romanın içeriğine ustaca göndermeler yapıldığ 1 görülür.

Özellikle Irazca ve ailesinin karşılaştı̆̆ güçlüklerle birlikte bilinçaltı değerlendirmelerinin de yapıldığı romanın, topluma mal olan sosyal bir yönü olsa da bu eser, öncelikle tezli bir köy romanıdır; ancak Karataş'tan hareketle, yazılan dönem içerisinde, aslında bütünüyle Anadolu coğrafyasının ve Anadolu insanının ruhunu betimler. $\mathrm{Bu}$ yönüyle aslında bizden olanı sunan yazar, romanın içselleştirilmesinde yardımcı bir rol üstlenir. 
Hakim bakış açısının uygulandığı roman, Anadolu insanının hayata karşı tutunma çabasını gözler önüne sererken zaman bağlamında kronolojik bir sıra izler. Hakim anlatıcı olmanın verdiği özelliğiyle, "roman kişilerinin görünen yüzü ile iç yüzünü aynı düzlemde aktaran” (Eliuz 2008:909) yazar, karakterlerin çok yönlülügünü sistematik bir sira içerisinde ortaya koyarak okura anlamda derinlik sunar. Bu yönüyle anlatım içerisinde bir düzen ve akıc1lık söz konusudur.

Dört vaka halkası ve kırk altı bölüm olarak incelenebilen romanda, olaylar arası geçişler parçadan bütüne bir seyir izler. Roman yazarının, anlamda bütünlüğün sağlanabilmesi için birbirini tamamlayıcı bir yaklaşımla bağladığı bölümler, vaka halkalarını oluşturur. Vaka halkaları arasındaki geçişlerin ise birbirini aydınlatıcı nitelikte oluşu, yazarın, sonuca ulaşırken bütüncül bir yol izlediğini gösterir.

Mekan, "zamanın sonsuz akışında yitip gitmek istemeyen insanın tutunduğu 'dışardaki içerdelik' niteliğinde bir yer” (Korkmaz 2015:80) olduğundan, yazar tarafından tüm yönleriyle ele alınır. Yazar; çevresel mekanlara, karakterlerin içselleştirebilme/tutunabilme düzeylerine göre algısal bağlamda değerler kazandırır. Böylece yazar; bir yandan açık/geniş, kapalı/dar ve labirentleşen mekanlarla anlamda zenginlik sunarken, diğer yandan olaylar arası geçişlerde öncelikle Irazca olmak üzere, tüm ana karakterlerin bilinçaltının dışavurumunda algısallıktan yararlanarak bu kişilerin mekanla olan uyumlarının olaya nasıl yön verdiğini ortaya koyar.

\section{Kaynakça}

AKTAŞ, Şerif (2000), Roman Sanatı ve Roman Incelemesine Giriş, Ankara: Akçağ Yayınları.

AŞKAROĞLU, Vedi (2016), "Romanlarda Kişilik Kurgusu: Kuramsal Bir Karşılaştırma”, Ordu Üniversitesi Sosyal Bilimler Araştırmaları Dergisi, S.14, s. 301-319.

BACHELARD, Gaston (2008), Uzamın Poetikası, (Çev. Alp Tümertekin), İstanbul: İthaki Yayınları.

İthaki Yayınları.

(2013), Mekânın Poetikası, (Çev. Alp Tümertekin), İstanbul:

BAKHTIN, Mikhail (2001), Karnavaldan Romana, (Çev. Sibel Irzik), İstanbul: Ayrıntı Yayınları.

BALDIRAN, Galip (2002), Alain Robbe-Grillet ve Yeni Roman, Konya: Çizgi Kitabevi Yayınları.

BAYKURT, Fakir (2010), Irazca ’nın Dirliği, İstanbul: Literatür Yayınları.

ÇETIN, Nurullah (2011), Roman Çözümleme Yöntemleri, Ankara: Öncü Kitap.

DEVECI, Mutlu (2007), “Anahtar Romanının Yap1 ve Tema Bakımından İncelenmesi”, Erdem, S. 49, s. 77-95.

ELİUZ, Ülkü (2008), “Orhan Kemal’in Murtaza Romanında Yapı”, Turkish Studies, C. 3/4, s. 904-921.

GASSET, Jose Ortega Y (2012), Sanatın Insansızlaştırılması ve Roman Üstüne Düşünceler, (Çev. Nevriye Gül Işık), İstanbul: Yapı Kredi Yayınları.

GÖKA, Şenol (2001), Insan ve Mekan, İstanbul: Pınar Yayınları.

KAPLAN, Ramazan (1997), Cumhuriyet Dönemi Türk Romanında Köy, Ankara: Akçağ Yayınları. 
KORKMAZ, Ramazan (1997), Sabahattin Ali (Insan ve Eser), İstanbul: Yap1 Kredi Yayınları.

(2002), "Romanda Dramatik Aksiyonu Sağlayan Değerlerin Görüntü Seviyeleri Üzerine Bazı Öneriler”, Scholary Dept and Accuracy, s. 217-281, Ankara: Grafiker Yayınları.

(Mustafa İsen'e Armă̆an), Ankara: Grafiker Yayınları.

(2007), "Romanda Mekânın Poetiği”, Edebiyat ve Dil Yazıları (2015), Yazınsal Okumalar, İstanbul: Kesit Yayınları.

LUKACS, Georg (2011), Roman Kuramı, (Çev. Cem Soydemir), İstanbul: Metis Yayınları.

MORAN, Berna (2008), Türk Romanına Eleştirel Bir Bakış-2, İstanbul: İletişim Yayınları.

RICOEUR, Paul (2007), Zaman ve Anlatı: bir (Zaman, Olayörgüsü, Üçlü Mimesis), (Çev. Mehmet Rifat-Sema Rifat), İstanbul: Yapı Kredi Yayınları.

STEVICK, Philip (2004), Roman Teorisi, (Çev. Prof. Dr. Sevim Kantarcıŏlu), Ankara: Akçağ Yayınları.

ŞAHIN, Eda (2006), Fakir Baykurt'un Köy Romanlarında Sosyal Yapı, (Yayımlanmamış Yüksek Lisans Tezi), Ege Üniversitesi Sosyal Bilimler Enstitüsü.

ŞAHIN, Veysel (2007), "Roman Tekniği Bakımından Yaban", e-Journal of New World Sciences Academy-Social Sciences, C. 2, S. 3, s. 179-196.

YANARDAĞ, Mehmet Fetih (2005), Fakir Baykurt'un Hikâye ve Romanlarının Tema ve Yapısı Üzerine Bir İnceleme, (Yayımlanmamış Doktora Tezi), İnönü Üniversitesi Sosyal Bilimler Enstitüsü. 